\title{
New data on the distribution and abundance of Dendrolimus sibiricus (Tshetverikov, 1908) (Lepidoptera: Lasiocampidae) in the Komi Republic.
}

Alexander Lukin ( $\square$ Lukin-6114@yandex.ru )

Institute of Biology of Komi Scientific Centre

\section{Research Article}

Keywords: siberian silkworm, quarantine object, environmental monitoring, conifers, pheromone trap

Posted Date: September 21st, 2021

DOl: https://doi.org/10.21203/rs.3.rs-900432/v1

License: (c) (i) This work is licensed under a Creative Commons Attribution 4.0 International License.

Read Full License 


\section{Abstract}

The Siberian silkworm (Dendrolimus sibiricus Tschetv.) is a defoliator pest that poses a significant threat to coniferous forest stands. Over the past decades, several large outbreaks of this species have occurred in Siberia (Russia), which has led to changes in forest ecosystems and an increase of expenses involved in reforestation. Adults capture new territories in the process of migration, therefore, a set of measures is needed to register the number and prevent further dispersal of the moth. One of methods of trapping is glue traps with synthetic pheromone. 16 district forestries located in the middle taiga subzone, with a total area of 151850 hectares, were surveyed as a part of the phytosanitary monitoring of the Siberian silkworm in the Komi Republic (Russia). Analysis of 773 pheromone traps showed 414 males of the target species that were identified by their genitals. The highest indicators of catchability were found in three district forestries. Taking into account the results obtained, it was proposed to continue the monitoring using the pheromone traps, to survey more northern forest districts and to carry out subsequent searches for preimaginal stages of the silkworm in the forest districts of Priluzsky district. The study will be useful for predicting the further spread of the silkworm and for developing optimal containment and control of the pest.

\section{Introduction}

Lepidoptera phyllophages have a significant impact on forest communities. The Siberian silkworm Dendrolimus sibiricus Tschetv. is a dangerous pest moth from the Lasiocampidae family, whose caterpillars feed on the foliage of conifers, mainly from the genera Abies, Pinus, Larix, Picea and Tsuga [1, 2].

Being widespread in Asia: Korea, China, Mongolia, Kazakhstan [3, 4, 5], it penetrated the territory of Siberia (Russia), from where it began to actively settle to the west of the country in the second half of the 20th century, having free access to host plants [6]. Within 25 years, from 1932 to 1957, D. sibiricus damaged 7 million hectares of forests and destroyed $50 \%$ of trees in Western Siberia and the Chita region $[3,7]$. For the period from 1994 to 1996, D. sibiricus damaged 700 thousand hectares of forest in the Krasnoyarsk Krai [8], and from 1954 to 1957, it destroyed more than 1.5 million hectares of pine in the area of the Ket and Chulym rivers [9]. In 2001, the activity of the pest was recorded in the Khabarovsk Krai on an area of more than 750 thousand hectares [10]. According to the research of Finnish scientists, the Siberian silkworm was recorded in the Perm Krai near the western foothills of the Ural Mountains [11]. Thus, these data reflect the active migration of the pest, which is a natural way to expand its habitat.

The Komi Republic is located in the northeastern part of the East European Plain. It is bounded from the territory of Siberia by the Ural Mountains in the east. And in the south it borders on the Perm Krai and the Kirov Region, where the presence of the Siberian silkworm has been reliably confirmed [12]. Most of the Komi Republic is covered with forest, the area of which is 28667.4 thousand hectares. Of the total plantations, spruce stands (Picea sp.) account for $56.4 \%$, pine (Pinus sp.) $-25.5 \%$, other conifers: fir (Abies sp.), larch (Larix sp.), Siberian pine (Pinus sibirica) Du Tour.) - 1.4\%, birch (Betula sp.) - 13.2\%, 
aspen (Populus sp.) $-3.4 \%$, other species $-0.1 \%$. The stock of coniferous wood in the forests is 2 356.36 million $\mathrm{m}^{3}$ (83.3\%) [13]. The proximity to the Siberian silkworm habitat and the species composition of the Komi Republic forests have become key factors for conducting environmental surveys. The hazard is not limited only to the distribution of silkworms, but also to the formation of the population that gives outbreaks of numbers.

The rapid increase in the number of individuals in the population is due to the peculiarities of the preimaginal stage. Caterpillars usually have a two- or three-year development cycle, depending on the combination of factors $[14,15,16]$. Dry weather periods are largely a prerequisite for the increase in number $[1,17,18,19]$. In the years of layering of the maturation of adults, an outbreak of the number of individuals occurs, followed by a massive release of caterpillars. Caterpillars of the Siberian silkworm, eating the needles, weaken the plant, and make it easily accessible for subsequent colonization by insects, mainly from the families (Cerambycidae, Buprestidae, Curculionidae) [20] and pathogenic microorganisms, whose vital activity reduces the quality of products from such wood. In case of severe damage, trees dry out, creating a threat of forest fire [10]. Thus, the Siberian silkworm is a direct ecological threat to the species composition of the forest community and the appearance of upland forests, as well as economic losses due to the deterioration of wood quality and the cost of reforestation.

Being a dangerous defoliator insect, this species currently has a regulatory status and is recognized as a quarantine object $[3,21]$. When establishing the scale of its distribution across Eurasia, I was guided by an interactive map from the official website of the European and Mediterranean Organization for Plant Protection (EPPO) (Fig. 1), according to which there is no information on the occurrence of the Siberian silkworm in the European northeast of Russia for 2020 [12].

At present, the study of the distribution of the Siberian silkworm in the European part of Russia is limited to studies of the more southern regions of the country $[22,23]$. The Komi Republic is rich in boreal forests, which can potentially be used by the pest to create a stable population. Lack of attention to the problem of the silkworm dispersal can cause outbreaks of numbers that lead to environmental and economic damage, as is the case of Siberia, as well as further expansion of the species towards Europe.

The study of the dynamics of the number and distribution of the population of individuals is carried out under the Order №23 of the Ministry of Agriculture validating the Regulation on the procedure for monitoring of quarantine phytosanitary state of the territory of the Russian Federation, which approved the procedure for the monitoring of territories [24]. The survey of the forest stands in the Komi Republic was carried out by the Federal Service for Veterinary and Phytosanitary Supervision in conjunction with the All-Russian Center for Plant Quarantine (FSBI «VNIIKR»). For the first time, 48 individuals of the Siberian silkworm were recorded in 2016 on the territory of 7 district forestries out of 12 surveyed [25]. When examining the same sites in 2017, the silkworm was found in all forest districts in the amount of 258 individuals [26]. In 2018, it was decided to expand the surveyed area to 14 district forestries. Analysis of 500 traps revealed 291 specimens of D. sibiricus [27]. 
Specially protected natural territories covering an area of 5.5 million hectares should be noted among other woodlands of the Komi Republic. The largest of them are Yugyd Va National Park and Pechorallych Nature Reserve [13]. The Virgin Forests of the Komi Republic are located on the designated areas. They are a UNESCO World Heritage Site and the largest massif of primary boreal forests in Europe, represented mainly by coniferous trees $[28,29]$. The invasion of the Siberian silkworm into these ecosystems will cause irreversible catastrophic consequences.

The present study aimed at identifying and counting the number of $D$. sibiricus adults in the district forestries of the Komi Republic using the glue traps with synthetic sex pheromone in 2020.

\section{Results}

The results of analysis of the contents of 773 traps are presented in the table (Table 1). During the survey of the Kajim district forestry in 2019, 11 Siberian silkworms were caught using 32 traps [27]. The moth was not registered in this area in 2020 , which is probably due to human factors. As a result of improper placement, some of the traps collapsed, which limited the contact of large moths (D. sibiricus) with the glue substrate inside. 
Table 1

The results of monitoring of the Siberian moth in the district forestry of the Komi Republic.

\begin{tabular}{|c|c|c|c|c|c|}
\hline Forestry & $\begin{array}{l}\text { District } \\
\text { forestry }\end{array}$ & $\begin{array}{l}\text { Surveyed } \\
\text { area, } \\
\text { (hectare) }\end{array}$ & $\begin{array}{l}\text { Number of } \\
\text { used traps } \\
\text { (pieces) }\end{array}$ & $\begin{array}{l}\text { Number of identified } \\
\text { specimens of } D \text {. } \\
\text { sibiricus (subject.) }\end{array}$ & $\begin{array}{l}\text { Catching } \\
\text { efficiency } \\
\text { of traps }\end{array}$ \\
\hline 1 & 2 & 3 & 4 & 5 & 6 \\
\hline \multirow[t]{6}{*}{ Priluzsky } & Zanulsky & 8450 & 43 & 56 & 2.6 \\
\hline & Obyachevsky & 4600 & 23 & 17 & 0.8 \\
\hline & Matyashsky & 2450 & 13 & 21 & 3.2 \\
\hline & Noshulsky & 15350 & 78 & 84 & 2.1 \\
\hline & Spasporubsky & 3000 & 15 & 13 & 1.7 \\
\hline & Lopinsky & 12600 & 63 & 34 & 1.1 \\
\hline Letsky & Lovlinsky & 3400 & 17 & 10 & 1.2 \\
\hline \multirow[t]{2}{*}{ Kazhimsky } & Kazhimsky & 3000 & 15 & 0 & 0 \\
\hline & Turuninsky & 10950 & 57 & 13 & 0.5 \\
\hline \multirow[t]{3}{*}{ Koygorodsky } & Uzhginsky & 5350 & 28 & 15 & 1.1 \\
\hline & Kobrinsky & 15200 & 79 & 22 & 0.6 \\
\hline & Koigorodsky & 18350 & 94 & 44 & 0.9 \\
\hline \multirow[t]{2}{*}{ Sysolsky } & Kuratovsky & 15250 & 77 & 24 & 0.6 \\
\hline & Vizingsky & 9900 & 51 & 18 & 0.7 \\
\hline \multirow[t]{2}{*}{$\begin{array}{l}\text { Troitsko- } \\
\text { Pechorsky }\end{array}$} & $\begin{array}{l}\text { Troitsko- } \\
\text { Pechorsky }\end{array}$ & 6000 & 40 & 17 & 0.9 \\
\hline & Beloborsky & 18000 & 80 & 26 & 0.7 \\
\hline In total: & & 151850 & 773 & 414 & \\
\hline
\end{tabular}

A significant number of $D$. sibiricus males were found in the Noshulsky and Zanulsky district forestries, which coincides with the monitoring data in 2019 [27]. A bit smaller number of D. sibiricus males was caught in the Koigorodsky and Lopyinsky district forestries. The designated areas are characterized by woodlands formed by light coniferous trees.

The Matyashsky district forestry surveyed for the first time showed the maximum catchability of the traps (3.2), which may be an indicator of a high pest density. Only one of 13 traps did not contain the target moth species. 
The Troitsko-Pechorsky and Beloborsky district forestries showed approximately the same catchability of the traps in 2020. In the previous year, only one specimen of the Siberian silkworm had been found in these territories. The traps were found to have been in operation from 1st August to 9th August which led to the poor collection. This fact should help to study the life cycle of the pest in the middle taiga in the Komi Republic, since it testifies to the cessation of adult activity by the end of July.

In order to predict the distribution of the moth, it is necessary to take into account that the boundaries of the habitat of the species are variable. The area changes its contours and space over time because it is a dynamic system [30]. This is especially pronounced in migratory species. It is assumed that the Siberian silkworm entered the territory of the Komi Republic through its southern border with the neighboring regions (the Perm Krai and the Kirov Region); since in the east the Komi Republic is bounded by the Ural Mountains, which create a natural barrier for the moth. At the moment, it is difficult to determine the exact date when the Siberian silkworm penetrated the territory of the Republic. The first recorded finding for the region was a female of $D$. sibiricus found near the village of Yaksha (the Troitsko-Pechorsky District) in 2014 [31]. Annual monitoring using the pheromone traps shows a positive result starting from 2016.

Probably, the relocation of $D$. sibiricus adults occurs along the southern border of the Republic, slightly entering the north of the region. The transport network of roads and felling areas can probably be used by the pest as "corridors" to facilitate its resettlement. An increase in the number of the adults caught in light coniferous forest stands is observed, which is probably due to the sparseness of trees, which also contributes to its distribution.

There are no confirmed findings of the preimaginal stages for the period 2016-2020, however, it can be argued that there is a population of this species on the territory of the Komi Republic. The traps were placed at a distance greater than the action of the pheromone, so that the adults from the adjacent regions were unable to detect it. It is also necessary to exclude the possibility of the specimens that penetrated the Komi Republic as a result of natural migration from the Perm Krai and the Kirov Region being captured into the traps. According to observations [32,33] adults are capable of flying at distances of $15-50 \mathrm{~km}$, which is not enough for being captured into most of the traps.

It should be noted that during the monitoring period of the Siberian silkworm, 23 specimens of a sympatric species, the Pine silkworm (Dendrolimus pini L.), were captured into the pheromone traps in addition to the target species. The Pine silkworm has long been known for the territory of the Komi Republic as a widespread pest of conifers [34, 35]. In 2020, adults were retrieved from the traps placed in the Troitsko-Pechorsky (3 individuals) and Beloborsky (20 individuals) district forestries. Their identification was carried out by the structural features of the genitals (Fig. 3), since it was impossible to identify them by external features.

The traps also included Lepidoptera from the families: Geometridae, Noctuidae, Notodontidae, Erebidae and Hepialidae, which were not included in the current research. 


\section{Discussion}

The highest rate of catchability of the traps was determined in the previously unexplored Matyashsky forestry during the forest monitoring process. The expectedly large number of $D$. sibiricus males was found in the Noshulsky and Zanulsky district forestries. All three territories are part of the Priluzsky District, located in the south-western part of the

Republic. In addition, a high number of silkworm individuals was caught in the Koygorodsky district forestry of the Koygorod District, located in the south of the Komi Republic. It is assumed that the Siberian silkworm has spread to some degree throughout the districts along the entire southern border of the Komi Republic. At this stage, it is impossible to reliably determine the relation of the pest to a certain type of the forest, since the caught individuals are only males. However, there is a tendency towards a larger number of the specimens to be caught in light coniferous forests. This species is characterized by active dispersal, so we can assume that it will move deeper into the region, having access to host plants.

The habitual diet of the Siberian silkworm caterpillars consists mainly of Larix sibirica, Abies sibirica, Pinus sibirica, but in the absence of these forage plants, they are able to switch to feeding on other breeds from the Pinaceae family [16, 36, 37]. Since most of the Komi forests are represented by conifers there is a real threat of the formation of large foci of this pest in the republic.

It should be noted that in order to determine the distribution zone and develop a strategy for further actions concerning the Siberian silkworm at the legislative level, it is necessary to detect the preimaginal stages. In order to do that, in our opinion, more attention should be paid to the district forestries, in which the largest number of the Siberian silkworm adults has been fixed for several years.

The use of the pheromone traps during the monitoring helped to capture the adult silkworms in the surveyed area with significant time savings. In the future, if signs of damage to the needles are found, it is planned to use the method of pounding, as well as to survey the soil around defoliated trees to find the preimaginal stages.

\section{Materials And Methods}

\subsection{The studied forestry sites}

All sites selected for the monitoring were located between parallels $59^{\circ} 47^{\prime} \mathrm{N}$ and $62^{\circ} 52^{\prime} \mathrm{N}$, which corresponds to the middle taiga subzone. The survey sites of the Vizingsky, Kuratovsky, Lopinsky, Noshulsky and Uzhginsky district forestries were represented by light-coniferous forests with a predominant tree species of Scots pine. The survey sites of the Zanulsky, Obyachevsky, Koygorodsky, Kazhimsky and Turuninsky district forestries included approximately equal parts of Scots pine and European spruce. The sites of the Spasporubsky, Matyashsky, Lovlinsky and Kobrinsky district forestries are represented by dark-coniferous forests consisting of European spruce. Scots pine and European spruce equally grew on the sites of the Troitsko-Pechorsky and Beloborsky district forestries. The 
presence of fire-sites of different age resulting from surface and ladder fires and raised bogs adjacent to the studied areas should be noted.

\subsection{Pheromone traps}

The object of the study was adult specimens of $D$. sibiricus males. The individuals were caught using adhesive traps with synthetic female sex pheromone synthesized by the FSBI «VNIIKR». The attractant was a mixture of substances Z5,E7-dodecadienal and Z5,E7-dodecadienol (1:1 by volume) [37], which were applied to a silicone plate before placing the traps. The traps had four faces with a total internal glue surface of $874 \mathrm{sq} . \mathrm{cm}$. The traps were placed in forests with predominantly coniferous tree species: Scots pine (Pinus sy/vestris L.), Siberian spruce (Picea obovata Ledeb.), Scots spruce (Picea abies (L.) Karst), Siberian larch (Larix sibirica Ledeb.), Siberian pine (Pinus sibirica Du Tour.) at a distance of $200 \mathrm{~m}$ from each other, mainly along forest paths and along the perimeter of forest clearings, as well as near the areas damaged by forest fires. The study of the activity of $D$. sibiricus was carried out from 2 nd July to 20th August in 2020 (50 days) on the territory of 16 district forestries of the Komi Republic (Table 1).

\subsection{Material processing}

The collected traps were packed, sealed and delivered to the testing laboratory of the branch of the FSBI "All-Russian Plant Quarantine Center" in the Komi Republic. The examination of the traps was carried out in accordance with the organization's guidelines [6]. In the first stage the traps were visually inspected for the presence of the pest adults. There was a strong degree of damage to moths, resulting in the possibility of identification only by morphological features of the genitals. Then the "cold" method of tissue removal was used to obtain the genitals: the cut-off end of the abdomen was placed in a $10 \%$ potassium hydroxide solution and remained in it for a day. Identification based on the characteristics of anatomical structures was carried out in accordance with the Guidelines [6]. The preparations of the genitals (Fig. 2) were stored in a glycerin solution. It should be noted that for greater reliability of the identification of the Siberian silkworm males, first detected during the monitoring in 2016, a DNA sequencing method was used, which showed a positive result.

To compare the number of the Siberian silkworms among the forestries, the catchability was calculated per 100 trap-days for each district forestry using the Eq. (1):

$$
\mathrm{X}=\frac{\mathrm{N} * 100}{\mathrm{n} * \mathrm{t}}
$$

where $X$ is the catchability (efficiency) of the traps; $N$ is the number of individuals caught; $n$ is the number of the installed traps; $t$ is the exposure time of the traps $[38,39]$. The results obtained are reflected in column 6 (Table 1 ).

\section{Declarations}

\section{ACKNOWLEDGEMENTS}


I would like to express my gratitude to the Federal Service for Veterinary and Phytosanitary Supervision in the Komi Republic for providing the opportunity to take part in the monitoring of the forestries.

\section{CONFLICT OF INTEREST}

The author declares that there is no conflict of interest.

\section{References}

1. Rozhkov, A. The Siberian moth: Systematic position, phylogeny, distribution, economic significance, structure and way of life, ed. by the USSR Academy of Sciences Publishing House, Moscow, 175 $\mathrm{p}(1963)$.

2. Epova, V. I. \& Pleshanov, A. S. The forest regions injured by phyllophagous insects in the Asian Russia46 p(Nauka Publ, Novosibirsk, 1995).

3. EPPO Data Sheets on Quarantine Pests. Dendrolimus sibiricus and Dendrolimus superans. Bulletin EPPO/EPPO Bulletin, 35, 390-395, https://gd.eppo.int/download/doc/932_ds_DENDSP_en.pdf. (2005).

4. Baker, R. et al. Dendrolimus sibiricus $\mathbb{P e s t}$ Report and Datasheet to support ranking of EU candidate priority pests EFSA. DOI: 10.5281/zenodo.2789554, (2019).

5. Flø, D., Rafoss, T., Wendell, M. \& Sundheim, L. The Siberian moth (Dendrolimus sibiricus), a Pest Risk Assessment for Norway. Forest Ecosystems, 7, 48 https://doi.org/10.1186/s40663-020-00258-9 (2020).

6. Methodological recommendations for detection and identification of Dendrolimus sibiricus Tshetv. (MR-vniikr №27-2014), ed. by FSBI "VNIIKR", Moscow, pp. 1-57.

7. Baranchikov, Y. N., Montgomery, M. E. \& Chapter, X. X. X. V. I. Siberian moth, edby Driesche RV, Reardon R The Use of Classical Biological Control to Preserve Forests in North America, Morgantown, pp. 383-391. https://bugwoodcloud.org/resource/files/14888.pdf., (2014).

8. Zhirin, V. M., Knyazeva, S. V. \& Eydlina, S. P. Long-term dynamics of vegetation indices in dark coniferous forest after Siberian moth disturbance. Contemporary Problems of Ecology, 9, 834-843 https://doi.org/10.1134/S1995425516070118 (2016).

9. Kharuk, V. I., Demidko, D. A., Fedotova, E. V., Dvinskaya, M. L. \& Budnik, U. A. Spatial and temporal dynamics of Siberian silk moth large-scale outbreak in dark-needle coniferous tree stands in Altai. Contemporary Problems of Ecology, 9, 711-720 https://doi.org/10.1134/S199542551606007x (2016).

10. Nifontov, S. V., Savchenko, A. A. \& Gridnev, A. N. Monitoring the development and forecasting of the mass reproduction (gradation) outbreaks of the Dendrolimus sibiricus Tschetv. in the Khabarovsk region. In Proceedings of the IV scientific-technical conference: Forests of Russia: policy, industry, science and education; 2019 May 22-24; St. Petersburg, 316. DOI: 10.1088/17551315/316/1/012043, (2019). 
11. Mikkola, K. \& Stahls, G. Morphological and molecular taxonomy of Dendrolimus sibiricus Chetverikov stat. rev. and allied lappet moths (Lepidoptera: Lasiocampidae), with description of a new species. Entomologica Fennica, 19 (2), 65-85 https://doi.org/10.33338/ef.84417 (2008).

12. EPPO Global database. Dendrolimus sibiricus (DENDSI) World distribution. https://gd.eppo.int/taxon/DENDSI/distribution.

13. Polshvedkin, R. V. (Chief Editor), Shchuki,n E.A., Ermakov, A.A., Kirosova, O.V., Chuprova, E.V. State report "On the state of the environment of the Komi Republic in 2019", ed. by Ministry of Natural Resources and Environmental Protection of the Komi Republic, GBU RK "Territorial Information Fund of the Komi Republic", Syktyvkar, pp. 1-162. https://gov.rkomi.ru/sites/gov/files/inline-files/ Госдоклад-2019_электронная\%20версия_1.pdf, (2020).

14. Prozorov, S. S. Siberian moth in fir forests of Siberia. Proceedings of the Siberian ForestTechnological Institute, Krasnoyarsk, pp. 93-132(1952).

15. Boldaruev, V. O. The Siberian moth fecundity and food suitability. Russian Zoology Journal, 34, 810821 (1955).

16. Kirichenko, N. I., Baranchikov, Y. N. \& Vidal, S. Performance of the potentially invasive Siberian moth Dendrolimus superans sibiricuson coniferous species in Europe. Agricultural and Forest Entomology, 11, 247-254 https://doi.org/10.1111/j.1461-9563.2009.00437.x (2009).

17. Kondakov, Y. P. Regularities of mass reproduction of the Siberian silkworm. Ecology of populations of forest animals in Siberia, ed. by Nauka Publ, Novosibirsk, pp. 206-265(1974).

18. Vashchuk, L. N., Popov, L. V. \& Krasny, N. M. Forests and forestry of the Irkutsk region, Irkutsk, 288 $\mathrm{p}(1997)$.

19. Chikidov, I. The role of climatic factors in the development of foci of mass reproduction of the Siberian silkworm in Central Yakutia in 1998-2001. Bulletin of the North-Eastern Federal University, 6 (3), 8-12 (2009).

20. Averinsky, A. I. \& Isaev, A. P. Formation of groups of stem pests in the foci of the Siberian silkworm in the forests of central Yakutia. Povolzhsky ecological journal, 1, 2-13 (2011).

21. Flø, D., Rafoss, T., Sundheim, L. \& Wendell, M. Pest risk assessment of Dendrolimus sibiricus and Dendrolimus superans. The Norwegian Scientific Committee for Food and Environment (VKM) Report, 2018:08, pp. 1-69(2018).

22. Möykkynen, T. \& Pukkala, T. Modelling of the spread of a potential invasive pest, the Siberian moth (Dendrolimus sibiricus) in Europe. Forest Ecosystems, 1, 10, https://doi.org/10.1186/s40663-0140010-7 (2014).

23. Jeger, M. et al. Grégoire, J.-C. Pest categorisation of Dendrolimus sibiricus. EFSA Journal, Vol. 16 (6), 1-29 https://doi.org/10.2903/j.efsa.2018.5301 (2018).

24. Order of the Ministry of Agriculture of the Russian Federation of January 23, №23 "On approval of the procedure for organizing monitoring of the quarantine phytosanitary state of the territory of the Russian Federation", Moscow http://www.fao.org/faolex/results/details/ru/c/LEX-FAOC178344/, (2018). 
25. Lukin, A. V. Detection centers of the Siberian moth in the Republic of Komi. Plant protection and quarantine, 11, 35-36 (2017).

26. Lukin, A. V. Distribution of the Siberian silkworm (Dendrolimus sibiricus Tchetv.) In the Komi Republic. In Proceedings of the Materials of the III All-Russian (XVIII) Youth Scientific Conference (with elements of a scientific school) ed. by IB FRC Komi SC UB RAS; 2018, Mar. 12-16 Syktyvkar, pp. 29-30., (2018).

27. Lukin, A. V. Distribution and population dynamics of the Siberian silkworm (Dendrolimus sibiricus Tschetv.) in the Komi Republic. In Proceedings of the XXVII All-Russian Youth Scientific Conference (with elements of a scientific school), ed. by IB FRC Komi SC UB RAS; 2020 Mar. 16-20 Syktyvkar, pp. 18-22. DOI: 10.31140/book-2020-03, (2020).

28. Alekseeva, R. N., Gladkov, V. P. \& Degteva, S. V. Cadastre of protected natural areas of the Komi Republic, part 2, Syktyvkar, $60 \mathrm{p}(1995)$.

29. The Virgin Komi Forests. https://whc.unesco.org/en/list/719/

30. Gorodkov, K. B. Ranges types of insects of tundra and forests zones of European Part of USSR, ed. by Nauka, Leningrad, pp. 3-20(1984).

31. Tatarinov, A. G., Kulakova, O. I., Mazeeva, A. V. \& Lukin, A. V. New materials on landscape distribution and ecology of Lepidoptera in the Komi Republic and the Kirov Province. Eversmannia. Entomological research in Russia and neighboring regions, 61, 74-78 (2020).

32. Boldaruev, V. O. Dynamics of a Siberian moth population and its parasitoids, ed. by Buryat Book Publishing house, Ulan-Ude., 164 p(1969).

33. Petko, V. M. \& Krasnoyarsk Pheromone monitoring of the Siberian moth populations. Abstract of PhD thesis, Sukachev Institute of Forest SB RAS, 18 p(2004).

34. Sedykh, K. F. Fauna of the Komi ASSRp. 145(Invertebrates, Syktyvkar, 1974).

35. Tatarinov, A. G., Sedykh, K. F. \& Dolgin, M. M. Fauna of the European North-East of Russia. Higher Heterocera Lepidoptera. Volume 7. Part 2 St. Petersburgpp. 52-55(Russian Academy of Sciences and Publishing House Nauka, 2003).

36. Kharuk, V. I., Im, S. T., Ranson, K. J. \& Yagunov, M. I. Climate-induced northerly expansion of Siberian silkmoth range. Forests, 8 (8), 301 https://doi.org/10.3390/f8080301 (2017).

37. Wilstermann, A., Schrader, G., Kinkar, M., Vos, S. E. F. S. A. \& European Food Safety Authority). (. Pest survey card on Dendrolimus sibiricus. EFSA supporting publication 2020:EN-1779. 23 p. DOI: 10.2903/sp.efsa.2020.EN-1779, (2020).

38. Pletnev, V. A., Ponomarev, V. L., Vendilo, N. V., Kurbatov, S. A. \& Lebedeva, K. V. Search of the pheromone of Siberian silkworm Dendrolimus superans sibiricus (Lepidoptera: Lasiocampidae). Agrochemistry (Agrokhimiya) 6, 67-72., (2000).

39. Karaseva, E. V. \& Telitsyna, A. Y. Techniques for studying rodents in the fieldNauka, 189 p(Moscow, 1996). 
40. Kotelnikova, T. A. \& Maslennikova, O. V. Dynamics of the number of small mammals in the Central Siberian nature reserve. In Proceedings of the Materials of the XIII All-Russian scientific-practical conference with international participation, ed. by Vyatka State University; 2018 Apr 23-24 Kirov, pp. 239-243., (2018).

\section{Figures}

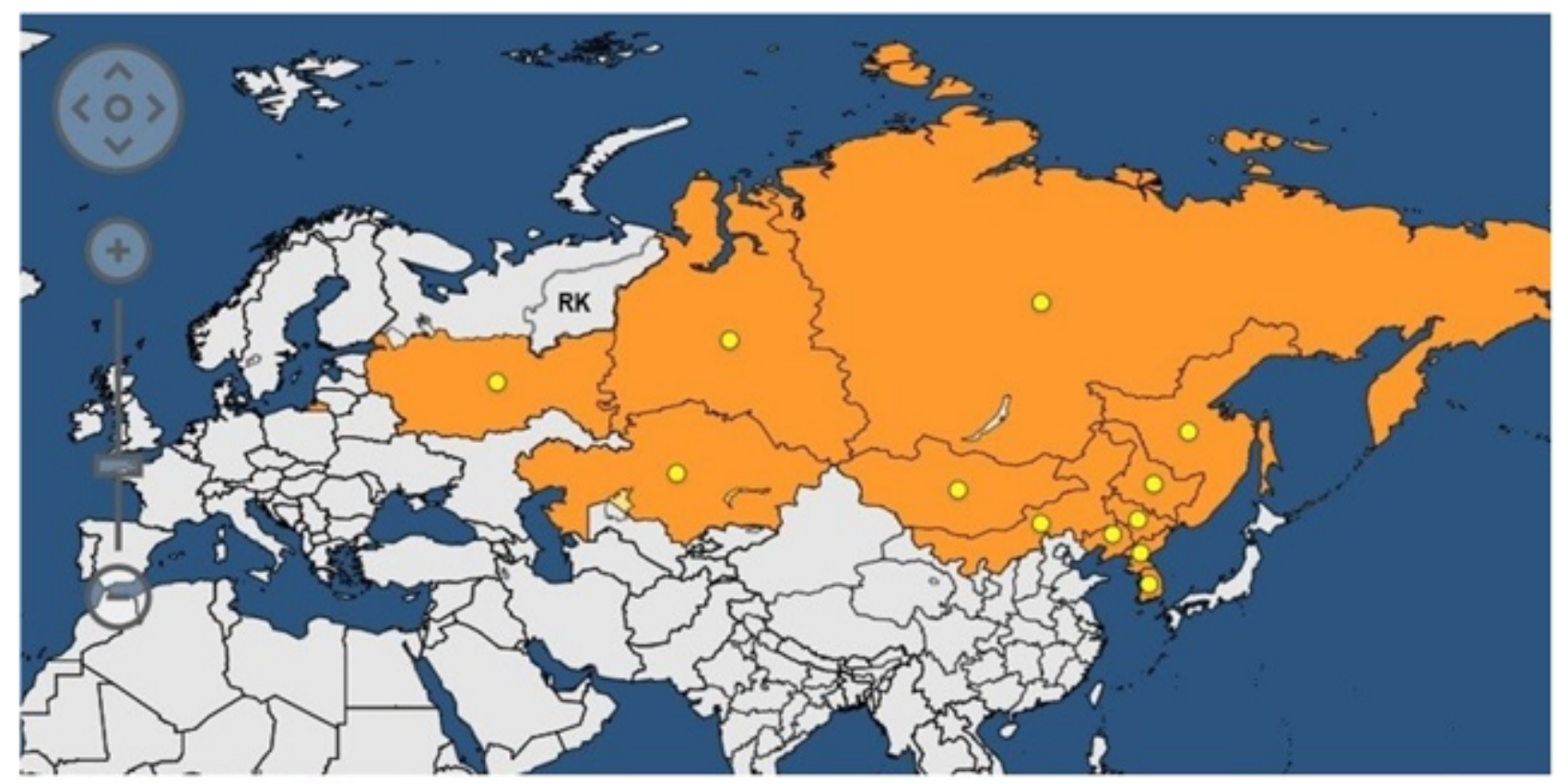

Legend: $O$-Present; - -Transient; RK - the Komi Republic

\section{Figure 1}

See image above for figure legend.

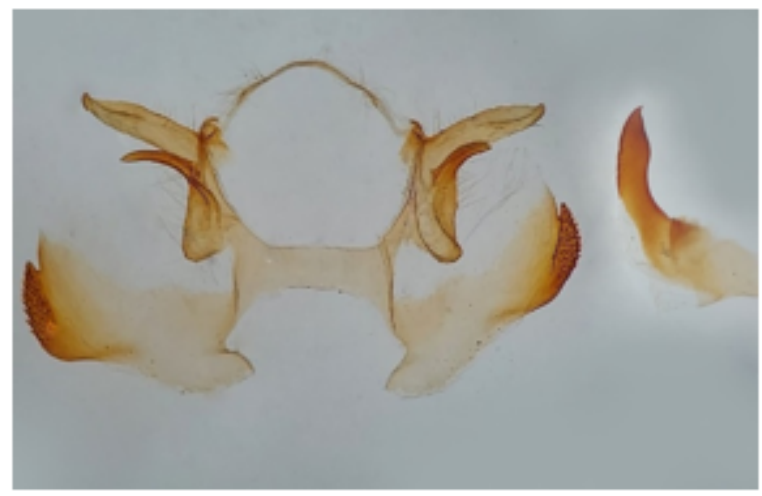

Figure 2. Microscope specimen of male genitalia of Dendrolimus sibiricus Tschetv. The aedeagus is separated. (enlarged 20 times).

Figure 2

See image above for figure legend. 


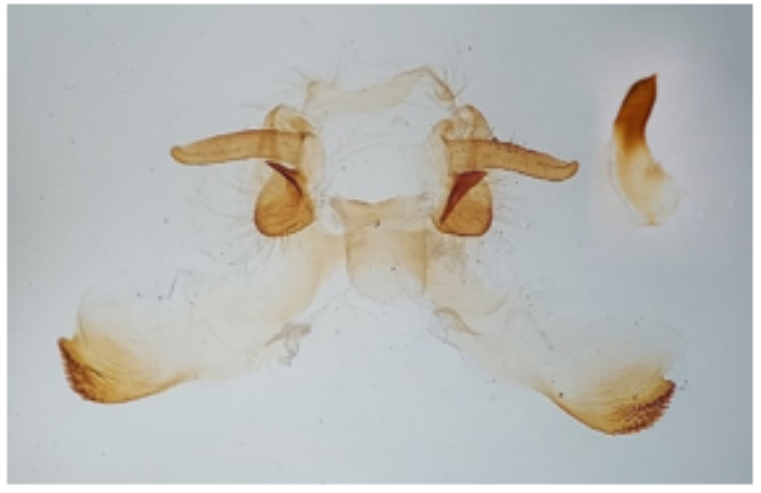

Figure 3. Microscope specimen of male genitalia of Dendrolimus pini $\mathrm{L}$. The aedeagus is separated. (enlarged 20 times).

\section{Figure 3}

See image above for figure legend. 